\title{
Analysis of the Sensitivity of Spring Wheat and White Mustard Seedlings to the Essential Oil of Parsley Seeds ${ }^{\dagger}$
}

\author{
Beata Jop ${ }^{1, * \mathbb{D}}$, Karolina Wawrzyńczak ${ }^{2}$, Karolina Polaszek ${ }^{1}$ and Agnieszka Synowiec ${ }^{1} \mathbb{D}$ \\ 1 Department of Agroecology and Crop Production, The University of Agriculture in Krakow, \\ 31-120 Kraków, Poland; karolina.polaszek@student.urk.edu.pl (K.P.); a.synowiec@urk.edu.pl (A.S.) \\ 2 Institute of Natural Products and Cosmetics, Lodz University of Technology, 90-924 Łódź, Poland; \\ karolina.wawrzynczak@edu.p.lodz.pl \\ * Correspondence: beata.jop@urk.edu.pl \\ + Presented at the 1st International Electronic Conference on Agronomy, 3-17 May 2021; Available online: \\ https://sciforum.net/conference/IECAG2021.
}

\begin{abstract}
Essential oils are a rich source of compounds for botanical pesticides. This study aimed to characterize the chemical composition of essential oil from parsley seeds and its phytotoxicity against the germination and initial growth of wheat and mustard. The main compounds of the oil were $\alpha$-pinene, $\beta$-pinene, and apiol. In a Petri dish experiment, the oil inhibited germination of seeds of both species. However, the growth of seedlings of both species was more inhibited, especially for wheat. In conclusion, parsley oil displays phytotoxic potential against the studied species, which should also be tested in soil conditions and against weeds.
\end{abstract}

Keywords: chemical composition; phytotoxicity; ED50

\section{check for}

updates

Citation: Jop, B.; Wawrzyńczak, K.; Polaszek, K.; Synowiec, A. Analysis of the Sensitivity of Spring Wheat and White Mustard Seedlings to the Essential Oil of Parsley Seeds. Biol. Life Sci. Forum 2021, 3, 12. https:// doi.org/10.3390/IECAG2021-09710

Academic Editor: Youssef Rouphael

Published: 1 May 2021

Publisher's Note: MDPI stays neutral with regard to jurisdictional claims in published maps and institutional affiliations.

Copyright: (c) 2021 by the authors. Licensee MDPI, Basel, Switzerland. This article is an open access article distributed under the terms and conditions of the Creative Commons Attribution (CC BY) license (https:// creativecommons.org/licenses/by/ $4.0 /)$.

\section{Introduction}

Garden parsley (Petroselinum crispum (Mill.) Fuss.) is a species of flowering plant in the family Apiaceae, a well-known vegetable of edible leaves and roots [1]. Seeds of parsley contain edible oil [2], but also essential oil [3,4]. The essential oil of parsley has several properties, including antioxidant and laxative $[5,6]$. The oil also displays insecticidal effects [7] but the phytotoxic effects of parsley oil have not yet been studied. However, Dhima et al. [8] studied the competitiveness of parsley against weeds in field conditions, and they found that it was a poor weed competitor, that reduced weed infestation only up to $30 \%$.

The market faces a continuous decrease in the number of synthetic herbicides for weed control due to the emergence of resistant biotypes and adverse impacts of herbicides on the environment [9]. In this context, the demand for safe green products increases, and research on natural products with herbicidal activity is of particular interest for producers and consumers $[10,11]$. Essential oils of plant origin are a rich source of biologically active compounds that could be applied in the future as natural, botanical herbicides [12,13]. Therefore, this work aimed at chemical analysis of the essential oil from parsley seeds and their phytotoxic effect against germination and seedling growth of spring wheat (Triticum aestivum L.) and white mustard (Sinapis alba L.).

\section{Materials and Methods}

Seeds of garden parsley (Petroselinum crispum (Mill.) Fuss.) were collected from southern Poland's organic fields (Krakowska Hodowla i Nasiennictwo Ogrodnicze Polan sp. z o. o.) in summer 2017. Seeds were milled and hydrodistilled for four hours using the Deryng apparatus [14]. A resulting essential oil (EO) was dried with $\mathrm{MgSO}_{4}$. Next, the EO was analyzed by gas chromatography coupled with mass spectrometry (GC-FID-MS), using a Trace GC Ultra gas chromatograph coupled with a DSQ II mass spectrometer 
(Thermo Electron Corporation). The percentages of constituents were computed from the GC peak area without using a correction factor [12]. Identification of the components was based on comparing their mass spectra and linear retention indices (RI, non-polar column) with those in [15] and computer libraries NIST 2011 and MassFinder 4.1.

Until testing, the parsley EO was stored in a dark glass in a cool place. The biological tests were performed in three replications, two series and two seasons, 2018 and 2020. Seeds of spring wheat cv. Harenda (breeder: MHR, PL) in 2018 and Blondynka (breeder: IHAR, ZD Grodkowice, PL) in 2020, and white mustard cv. Borowska (breeder: MHR, PL) were used. Oil in water $(\mathrm{o} / \mathrm{w})$ emulsions with the five EO doses, namely, $0.6 \mathrm{~g}, 1.0 \mathrm{~g}, 1.4 \mathrm{~g}, 2.8 \mathrm{~g}$, and $4.3 \mathrm{~g} \mathrm{~L}^{-1}$ were prepared. A $2.0 \%$ aqueous solution of acetone was used as a carrier. Control was water with acetone only. The parsley EO's specific density was in the range $1.043-1.110 \mathrm{~g} \mathrm{~cm}^{-3}$ [16], which was why the EO and water with acetone were weighed out $(w / w)$. Dry and clean Petri dishes (11 cm diameter) were lined with two autoclaved filter paper pieces. Seven grams of o/w emulsion per dish was poured evenly. The emulsions contained $0.004,0.007,0.01 ; 0.02$ and $0.03 \mathrm{~g}$ EO per dish. The tested plants' seeds were first surface-sterilized with 5\% ethanol and rinsed with water. Next, 20 seeds of each species, separately, were placed in each dish. The dishes were put in thin polypropylene bags to reduce the $\mathrm{EO}$ evaporation and placed in a shaded place at a room temperature of $22 \pm 3{ }^{\circ} \mathrm{C}$. After seven days, the seedlings were counted, and their leaf/shoot and roots measured with a ruler. A dose-response test, using a 'drc' package in the R program ver. 3.5.3. [17], was performed. The ED50 value, i.e., a dose causing a 50\% reduction of a plant trait, was calculated for the percentage of germination and seedlings' leaves/shoots and roots length. One-way ANOVA for a randomized design was applied to test differences between the EO concentrations, and means were separated using the Tukey test. Since the series in 2018 and 2020 were significantly different, they were analyzed separately.

\section{Results and Discussion}

The average yield of the parsley EO was $0.76 \%$. In the analyzed parsley seed essential oil, 20 compounds were identified by GC-MS (Table 1). The main compounds constituted $98 \%$ of the oil. The analyzed EO's chemical composition was typical for this oil [3]. Main compounds were monotorpene hydrocarbons: $\alpha$-pinene $(37.1 \%), \beta$-pinene $(26.2 \%)$ and phenylopropanoid apiol (23.8\%). The three compounds accounted for almost $90 \%$ of the essential oil composition. Apiol is a well-known compound for its human toxic properties [18]. Apiol as well as myristicin (7.1\% in the essential oil) displays insecticide action with LD50 value around 10 ppm [19].

Table 1. Chemical composition of parsley oil with average content of main compounds [\%].

\begin{tabular}{cccc}
\hline Compound & $\mathbf{R I}_{\mathbf{e x p}} \mathbf{1}^{-}$ & $\mathbf{R I}_{\mathbf{l i t}} \mathbf{2}^{\mathbf{2}}$ & $\mathbf{[ \%}$ \\
\hline$\alpha$-Thujene & 928 & 926 & 37.1 \\
$\alpha$-Pinene & 932 & 936 & 0.2 \\
Camphene & 946 & 950 & 1.0 \\
Sabinene & 970 & 973 & 26.2 \\
$\beta$-Pinene & 976 & 978 & 0.2 \\
$p$-Cymene & 1012 & 1015 & 0.7 \\
$\beta$-Phellandrene & 1020 & 1024 & 0.5 \\
Limonene & 1023 & 1025 & 0.7 \\
$\gamma$-Terpinene & 1049 & 1051 & 0.1 \\
$\alpha$-Terpinyl acetate & 1333 & 1335 & 0.1 \\
$(E)$ - $\beta$-Farnesene & 1447 & 1446 & 7.1 \\
Myristicin & 1490 & 1489 & 23.8 \\
Apiol & 1651 & 1649 & \\
\hline
\end{tabular}

${ }^{1}$ RI exp-experimental retention index; ${ }^{2}$ RI lit-standard retention index.

The composition was qualitatively consistent with previous reports [20,21], however, 1-allyl-2,3,4,5, tetramethoxybenzene, a compound differentiating seed from leaf oil was 
not found. It has been proven that the proportions of compounds are varying between cultivars [21].

Both wheat cultivars displayed a different germination pattern in the presence of parsley EO. Table 2 shows that wheat cv. Harenda germinated at a much higher percent, even in the presence of the highest EO dose (Figure 1A), compared to cv. Blondynka. On the other hand, the EO strongly inhibited, by $>90 \%$, the elongation of both wheat cultivars' coleoptiles and roots, already at the lowest dose.

Table 2. Germination and seedlings growth of wheat cv. Harenda (an experiment in 2018) and cv. Blondynka (an experiment in 2020) in the presence of growing doses of parsley essential oil.

\begin{tabular}{ccccccc}
\hline \multirow{2}{*}{$\begin{array}{c}\text { Dose of EO } \\
\text { (g per Dish) }\end{array}$} & \multicolumn{3}{c}{ cv. Harenda } & \multicolumn{3}{c}{ cv. Blondynka } \\
\cline { 2 - 7 } & Germinated [\%] & Leaf [mm] & Root [mm] & Germinated [\%] & Leaf [mm] & Root [mm] \\
\hline 0 & $100 \pm 0$ & $62.2 \pm 2.25 \mathrm{a}^{1}$ & $100 \pm 9.69 \mathrm{a}$ & $91.7 \pm 3.6 \mathrm{a}$ & $24.4 \pm 3.91 \mathrm{a}$ & $48.3 \pm 1.29 \mathrm{a}$ \\
0.004 & $98.3 \pm 1.36$ & $5.38 \pm 0.47 \mathrm{~b}$ & $3.47 \pm 0.36 \mathrm{~b}$ & $11.7 \pm 5.93 \mathrm{~b}$ & $3.05 \pm 0.68 \mathrm{~b}$ & $4.88 \pm 1.31 \mathrm{~b}$ \\
0.007 & $98.3 \pm 1.36$ & $3.84 \pm 0.24 \mathrm{~b}$ & $2.47 \pm 0.16 \mathrm{~b}$ & $33.3 \pm 12.1 \mathrm{~b}$ & $1.95 \pm 0.39 \mathrm{~b}$ & $3.04 \pm 0.84 \mathrm{~b}$ \\
0.01 & $95.0 \pm 0$ & $2.21 \pm 0.35 \mathrm{~b}$ & $1.37 \pm 0.02 \mathrm{~b}$ & $18.3 \pm 3.6 \mathrm{~b}$ & $1.43 \pm 0.19 \mathrm{~b}$ & $1.50 \pm 0.11 \mathrm{~b}$ \\
0.02 & $83.3 \pm 1.36$ & $1.66 \pm 0.24 \mathrm{~b}$ & $1.32 \pm 0.06 \mathrm{~b}$ & $16.7 \pm 1.36 \mathrm{~b}$ & $1.17 \pm 0.14 \mathrm{~b}$ & $1.32 \pm 0.04 \mathrm{~b}$ \\
0.03 & $63.3 \pm 9.81$ & $1.33 \pm 0.16 \mathrm{~b}$ & $1.22 \pm 0.11 \mathrm{~b}$ & $13.3 \pm 2.72 \mathrm{~b}$ & $1.33 \pm 0.14 \mathrm{~b}$ & $1.10 \pm 0.01 \mathrm{~b}$ \\
ED50 & 0.04 & 0.002 & 0.0003 & 0.002 & 0.0004 & 0.003 \\
\hline
\end{tabular}

${ }^{1}$ diverse letter in the column denotes a significant difference between means, according to the Tukey test at $p<0.05$.

(A)

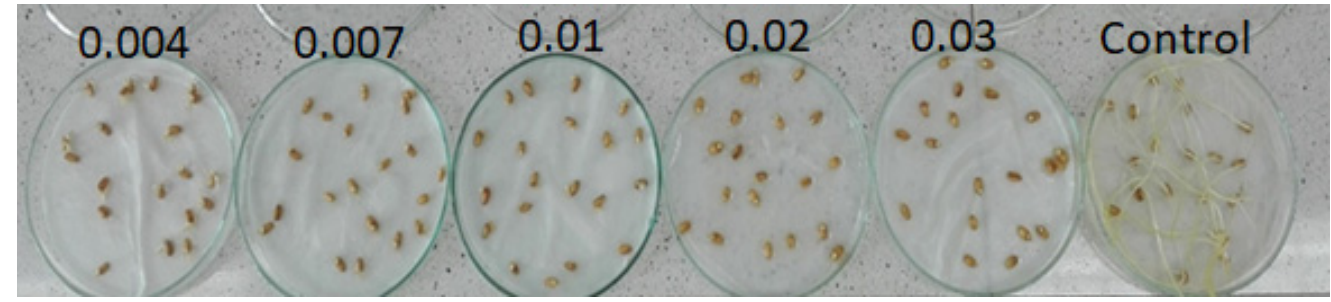

(B)

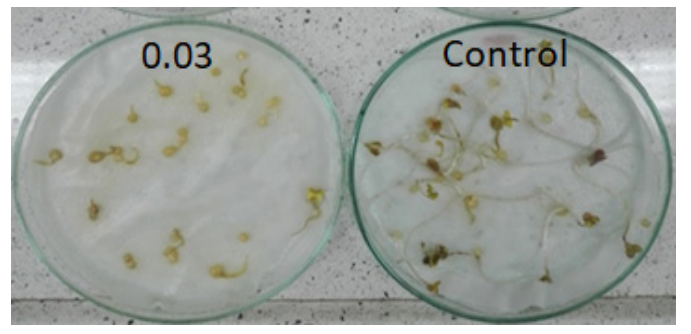

Figure 1. Seedlings of wheat cv. Harenda (A), and white mustard (B), after seven days of germination in the presence of growing doses of parsley essential oil.

Mustard germination and initial growth were also different between the seasons, especially in terms of germination percentage, which was higher in 2018 (Figure 1B). It was similar for the three highest doses of the EO (Table 3). Germination of mustard in 2020 showed a typical decreasing trend in response to the growing EO doses. At the same time, the ED50 dose for germination was similar for both studied seasons. In both seasons, mustard roots were more sensitive to the EO's presence compared to shoots. Shoots of mustard were inhibited in a range of $60-70 \%$ and $70-80 \%$, compared to control in 2018 and 2020 , respectively. The EO's three highest doses caused a decrease of root length by $60-80 \%$ and $60 \%$ in 2018 and 2020, respectively.

To date, there is scarce literature on the phytotoxic potential of parsley essential oil [8]. The methylene chloride extracts from seeds of two other species of Apiaceae botanical family, namely Ligusticum hultenii and Lomatium californicum, containing high amounts of apiol, one of the main compounds of the parsley EO, have been studied for phytotoxic effects against algae [22]. However, the authors found low phytotoxicity of those extracts. The 
current study's results point to the parsley oil's phytotoxic effect on wheat and mustard seedlings, which was more due to the inhibition of seedlings' growth than germination of seeds. The inhibition of plants' initial growth has an environmental dimension-plants that emerge slowly are less competitive with neighbor species [23]. On the other hand, considering that these experiments were performed in in vitro conditions, the phytotoxicity of parsley oil should be studied further in soil as a growth medium, which could potentially change the effects observed in the Petri dishes [24].

Table 3. Germination and seedlings growth of white mustard cv. Borowska during the experiments performed in 2018 and 2020 in the presence of growing doses of parsley essential oil.

\begin{tabular}{ccccccc}
\hline \multirow{2}{*}{$\begin{array}{c}\text { Dose of EO } \\
\text { (g per Dish) }\end{array}$} & \multicolumn{3}{c}{$\mathbf{2 0 1 8}$} & \multicolumn{3}{c}{$\mathbf{2 0 2 0}$} \\
\cline { 2 - 7 } & Germinated [\%] & Shoot [mm] & Root [mm] & Germinated [\%] & Shoot [mm] & Root [mm] \\
\hline 0 & $100 \pm 0 \mathrm{a}^{1}$ & $31.6 \pm 0.65 \mathrm{a}$ & $22.9 \pm 1.35 \mathrm{a}$ & $93.3 \pm 1.36 \mathrm{a}$ & $21.2 \pm 0.24 \mathrm{a}$ & $13.2 \pm 0.99 \mathrm{a}$ \\
0.004 & $43.3 \pm 3.6 \mathrm{c}$ & $13.2 \pm 0.91 \mathrm{~b}$ & $12.0 \pm 2.45 \mathrm{~b}$ & $63.3 \pm 2.72 \mathrm{~b}$ & $4.13 \pm 0.67 \mathrm{~b}$ & $9.41 \pm 0.54 \mathrm{~b}$ \\
0.007 & $65.0 \pm 6.24 \mathrm{~b}$ & $10.9 \pm 0.82 \mathrm{~b}$ & $10.3 \pm 1.80 \mathrm{~b}$ & $51.7 \pm 9.53 \mathrm{~b}$ & $5.46 \pm 0.22 \mathrm{~b}$ & $6.11 \pm 0.31 \mathrm{bc}$ \\
0.01 & $70.0 \pm 2.36 \mathrm{~b}$ & $9.30 \pm 1.03 \mathrm{~b}$ & $4.52 \pm 0.87 \mathrm{c}$ & $58.3 \pm 1.36 \mathrm{~b}$ & $6.77 \pm 0.04 \mathrm{~b}$ & $5.25 \pm 0.05 \mathrm{c}$ \\
0.02 & $75.0 \pm 4.08 \mathrm{~b}$ & $7.97 \pm 0.34 \mathrm{~b}$ & $5.21 \pm 0.71 \mathrm{c}$ & $50.0 \pm 6.24 \mathrm{~b}$ & $6.83 \pm 0.46 \mathrm{~b}$ & $5.02 \pm 0.43 \mathrm{c}$ \\
0.03 & $65.0 \pm 6.24 \mathrm{~b}$ & $9.36 \pm 1.60 \mathrm{~b}$ & $8.82 \pm 1.18 \mathrm{~b}$ & $35.0 \pm 8.50 \mathrm{c}$ & $6.38 \pm 0.29 \mathrm{~b}$ & $5.16 \pm 0.25 \mathrm{c}$ \\
ED50 & 0.03 & 0.0001 & 0.003 & 0.02 & 0.0004 & 0.0004 \\
\hline
\end{tabular}

${ }^{1}$ diverse letter in the column denotes a significant difference between means, according to the Tukey test at $p<0.05$.

\section{Conclusions}

To the authors' knowledge, this is the first report on the phytotoxic effect of parsley essential oil (EO). It was proved that the oil inhibits germination of both wheat and mustard, with mustard germination being more inhibited compared to wheat. On the other hand, the parsley oil strongly inhibits the elongation growth of seedlings of both species. Wheat leaf and root growth are negatively affected $(>90 \%)$ already at the lowest dose of parsley EO: $0.004 \mathrm{~g}$ per $7 \mathrm{~g}$ of $\mathrm{o} / \mathrm{w}$ emulsion, equal to $0.6 \mathrm{of} \mathrm{EO} \mathrm{g}$ per L o/w emulsion. Mustard response to the parsley EO is less than the wheat response and is dose-dependent, especially in root elongation. The study should be continued to assess parsley essential oil's effect on the germination of weed seeds and in different soil conditions.

Author Contributions: Conceptualization, A.S. and B.J.; methodology, A.S.; investigation, B.J., K.W. and K.P.; data curation, A.S., B.J., K.W. and K.P.; writing-original draft preparation, B.J., K.W. and K.P.; writing-review and editing, A.S.; visualization, A.S.; supervision, A.S. All authors have read and agreed to the published version of the manuscript.

Funding: This research received no external funding.

Institutional Review Board Statement: Not applicable.

Informed Consent Statement: Not applicable.

Data Availability Statement: Not applicable.

Acknowledgments: The authors thank Weronika Ciężka and Alicja Gąsiorowska for their technical support, and Milena Borek, for providing the parsley seeds used in this experiment.

Conflicts of Interest: The authors declare no conflict of interest.

\section{References}

1. Farzaei, M.H.; Abbasabadi, Z.; Ardekani, M.R.S.; Rahimi, R.; Farzaei, F. Parsley: A review of ethnopharmacology, phytochemistry and biological activities. J. Tradit. Chin. Med. 2013, 33, 815-826. [CrossRef]

2. Parry, J.; Hao, Z.; Luther, M.; Su, L.; Zhou, K.; Yu, L.L. Characterization of cold-pressed onion, parsley, cardamom, mullein, roasted pumpkin, and milk thistle seed oils. J. Am. Oil Chem. Soc. 2006, 83, 847-854. [CrossRef]

3. Simon, J.E.; Quinn, J. Characterization of essential oil of parsley. J. Agric. Food Chem. 1988, 36, 467-472. [CrossRef]

4. Petropoulos, S.A.; Daferera, D.; Polissiou, M.G.; Passam, H.C. The effect of water deficit stress on the growth, yield and composition of essential oils of parsley. Sci. Hortic. 2008, 115, 393-397. [CrossRef] 
5. Zhang, H.; Chen, F.; Wang, X.; Yao, H.Y. Evaluation of antioxidant activity of parsley (Petroselinum crispum) essential oil and identification of its antioxidant constituents. Food Res. Int. 2006, 39, 833-839. [CrossRef]

6. Kreydiyyeh, S.I.; Usta, J.; Kaouk, I.; Al-Sadi, R. The mechanism underlying the laxative properties of parsley extract. Phytomedicine 2001, 8, 382-388. [CrossRef] [PubMed]

7. Massango, H.G.L.L.; Faroni, L.R.A.; Haddi, K.; Heleno, F.F.; Jumbo, L.V.; Oliveira, E.E. Toxicity and metabolic mechanisms underlying the insecticidal activity of parsley essential oil on bean weevil, Callosobruchus maculatus. J. Pest Sci. 2017, 90, 723-733. [CrossRef]

8. Dhima, K.; Vasilakoglou, I.; Garane, V.; Ritzoulis, C.; Lianopoulou, V.; Panou-Philotheou, E. Competitiveness and essential oil phytotoxicity of seven annual aromatic plants. Weed Sci. 2010, 58, 457-465. [CrossRef]

9. Hasanuzzaman, M.; Mohsin, S.M.; Bhuyan, M.B.; Bhuiyan, T.F.; Anee, T.I.; Masud, A.A.C.; Nahar, K. Phytotoxicity, environmental and health hazards of herbicides: Challenges and ways forward. In Agrochemicals Detection, Treatment and Remediation, 1st ed.; Prasad, M.N.V., Ed.; Butterworth-Heinemann: Oxford, UK, 2020; pp. 55-99.

10. Lengai, G.M.; Muthomi, J.W.; Mbega, E.R. Phytochemical activity and role of botanical pesticides in pest management for sustainable agricultural crop production. Sci. Afr. 2020, 7, e00239. [CrossRef]

11. Damalas, C.A.; Koutroubas, S.D. Botanical Pesticides for Eco-Friendly Pest Management: Drawbacks and Limitations. In Pesticides in Crop Production: Physiological and Biochemical Action, 1st ed.; Srivastava, P.K., Singh, V.P., Singh, A., Tripathi, D.K., Singh, S., Prasad, S.M., Chauhan, D.K., Eds.; Wiley: Hoboken, NJ, USA, 2020; pp. 181-193.

12. Synowiec, A.; Kalemba, D.; Drozdek, E.; Bocianowski, J. Phytotoxic potential of essential oils from temperate climate plants against the germination of selected weeds and crops. J. Pest Sci. 2017, 90, 407-419. [CrossRef]

13. Fierascu, R.C.; Fierascu, I.C.; Dinu-Pirvu, C.E.; Fierascu, I.; Paunescu, A. The application of essential oils as a next-generation of pesticides: Recent developments and future perspectives. Zeitsch. Naturforsch. C 2020, 75, 183-204. [CrossRef] [PubMed]

14. Baj, T.; Sieniawska, E.; Kowalski, R.; Wesolowski, M.; Ulewicz-Magulska, B. Effectiveness of the deryng and clevenger-type apparatus in isolation of various types of components of essential oil from the Mutelina purpurea Thell. flowers. Acta Pol. Pharm. 2015, 72, 507-515. [PubMed]

15. Adams, R.P. Identification of Essential Oil Components by Gas Chromatography/Mass Spectrometry, 4th ed.; Allured Publishing Corporation: Carol Stream, IL, USA, 2007.

16. Acimovic, M.G.; Cvetkovic, M.T.; Stankowic, J.M.; Tesevic, V.V.; Todosijevic, M.M. Headspace Analysis of Volatile Compounds From Fruits of Selected Vegetable Species of Apiaceae Family. In Phytochemicals in Vegetables: A Valuable Source of Bioactive Compounds, 1st ed.; Petropoulos, S.A., Ferreira, I.C.F.R., Barros, L., Eds.; Bentham Science Publishers: Sharjah, United Arab Emirates, 2018; pp. 209-235.

17. R Core Team. R: A Language Andenvironment for Statistical Computing; R Foundation for Statistical Computing: Vienna, Austria, 2020; Available online: https:/ / www.R-project.org/ (accessed on 2 March 2020).

18. Alajlouni, A.M.; Al_Malahmeh, A.J.; Kiwamoto, R.; Wesseling, S.; Soffers, A.E.; Al-Subeihi, A.A.; Rietjens, I.M. Mode of action based risk assessment of the botanical food-borne alkenylbenzene apiol from parsley using physiologically based kinetic (PBK) modelling and read-across from safrole. Food Chem. Toxicol. 2016, 89, 138-150. [CrossRef] [PubMed]

19. Lichtenstein, E.P.; Liang, T.T.; Schulz, K.R.; Schnoes, H.K.; Carter, G.T. Insecticidal and synergistic components isolated from dill plants. J. Agric. Food Chem. 1974, 22, 658-664. [CrossRef] [PubMed]

20. Mert, A.; Timur, M. Essential oil and fatty acid composition and antioxidant capacity and total phenolic content of parsley seeds (Petroselinum crispum) grown in Hatay Region. Indian J. Pharm. Educ. Res. 2017, 51, 437-440. [CrossRef]

21. Kurowska, A.; Gałazka, I. Essential oil composition of the parsley seed of cultivars marketed in Poland. Flavour Fragr. J. 2006, 21, 143-147. [CrossRef]

22. Meepagala, K.M.; Sturtz, G.; Wedge, D.E.; Schrader, K.K.; Duke, S.O. Phytotoxic and antifungal compounds from two Apiaceae species, Lomatium californicum and Ligusticum hultenii, rich sources of Z-ligustilide and apiol, respectively. J. Chem. Ecol. 2005, 31, 1567-1578. [CrossRef] [PubMed]

23. Akhter, M.J.; Kudsk, P.; Mathiassen, S.K.; Melander, B. Rattail fescue (Vulpia myuros) interference and seed production as affected by sowing time and crop density in winter wheat. Weed Sci. 2021, 69, 52-61. [CrossRef]

24. Synowiec, A.; Krajewska, A. Soil or Vermiculite-Applied Microencapsulated Peppermint Oil Effects on White Mustard Initial Growth and Performance. Plants 2020, 9, 448. [CrossRef] [PubMed] 